\title{
STUDY OF THE MINERALIZATION OF THE WASTE FROM ANATOMY LABORATORIES OF THE UNDERGRADUATION COURSES OF THE FEDERAL UNIVERSITY OF JEQUITINHONHA AND MUCURI VALLEYS
}

\section{ESTUDO DA MINERALIZAÇÃO DOS RESÍDUOS DOS LABORATÓRIOS DE ANATOMIA DOS CURSOS DE GRADUAÇÃO DA UNIVERSIDADE FEDERAL DOS VALES DO JEQUITINHONHA E MUCURI}

\author{
M. C. SOUZA ${ }^{1}$ and J. A. SOUSA ${ }^{1}$
}

${ }^{1}$ Federal University of Jequitinhonha and Mucuri Valleys, Institute of Science and Technology, Diamantina, Minas Gerais, Brazil

${ }^{*}$ Corresponding author

e-mail address: jose.alberto@ict.ufvjm.edu.br

A R T I C L E I N F O
Article history:
Received 2018-07-14
Accepted 2018-11-05
Available online 2019-03-08
$k$ e y $w$ o $r d s$
Formalin degradation
Advanced oxidation processes
Chemical kinetic
Formaldehyde
$p$ a $l a v r a s-c h a v e$
Degradação de formalina
Processos de oxidação Avançada
Cinética química
Formaldehyde

Formaldehyde

\begin{abstract}
A B S T R A C T
In spite of it is a dangerous substance already defined as carcinogenic, formaldehyde even widely used in industry and in the academic environment, in Brazil, it still does not present a regulation that delimits what can be considered a safe disposal. Based on the literature, it was defined that $1.61 \mathrm{mg} \mathrm{L}^{-1}$ offormaldehyde represents a safe concentration to be lead to sewage. The proposal of this study is to establish a complete oxidation model of this residue, followed by its simulation using different types of reactor models. The entire process was structured to satisfy the demands from the human and animal anatomy laboratories, both present at Federal University of Jequitinhonha and Mucuri Valleys, in the city of Diamantina, MG. The corpses and carcass washing process implanted provides the effluent which will be treated. The reaction model has three stages, the first follows zero-order kinetics and the other two follow a pseudo-first order kinetic, their specific reaction rate were $0.0457 \mathrm{~mol} \mathrm{~L}^{-1} \mathrm{~min}^{-1}, 0.0702 \mathrm{~min}^{-}$ ${ }^{1}$ and $0.0144 \mathrm{~min}^{-1}$, respectively. A $150 \mathrm{~L} \mathrm{BSTR}$ presented satisfactory operation, with a batch time of 7 minutes to achieve a safe disposal. Further tests with the real effluent ought to be implemented in order to compare with the results from the synthetic effluent.

R E S U M O
\end{abstract}

Apesar de ser uma substância perigosa já definida como carcinogênica, o formaldeído ainda muito utilizado na indústria e no meio acadêmico, no Brasil ainda não há regulamentação que delimite um descarte seguro. Baseado na literatura, definiu-se que $1,61 \mathrm{mg} \mathrm{L}^{-1}$ de formaldeído representa uma concentração segura para ser despejada no esgoto. A proposta deste estudo é estabelecer um modelo completo de oxidação deste resíduo, seguido de sua simulação utilizando diferentes tipos de modelos de reatores. Todo o processo foi estruturado para atender às demandas dos laboratórios de anatomia humana e animal, ambos presentes na Universidade Federal dos Vales do Jequitinhonha e Mucuri, na cidade de Diamantina, MG. O processo de lavagem de cadáveres e carcaças fornece o efluente que será tratado. $O$ modelo da reação possui três estágios, o primeiro seguindo cinética de ordem zero e os outros dois com cinética de pseudo-primeira ordem, suas taxas específicas de reação foram 0,0457 $\mathrm{mol} \mathrm{L}^{-1} \mathrm{~min}^{-1}$, 0,0702 $\mathrm{min}^{-1}$ e 0,0144 $\mathrm{min}^{-1}$, respectivamente. Um BSTR de $150 \mathrm{~L}$ apresentou operação satisfatória, com tempo de batelada de 7 minutos para alcançar um descarte seguro. Testes adicionais com o efluente real devem ser realizados para que sejam comparados com os resultados do efluente sintético. 


\section{N O M E N C L A T U R E}

BSTR - Batch Stirred Tank Reactor;

COD - Chemical Oxygen Demand [mg L ${ }^{-1}$;

CSTR - Continuous Stirred Tank Reactor;

ETP - Effluent Treatment Plant;

PFR - Plug Flow Reactor; Valleys.

UFVJM - Federal University of Jequitinhonha e Mucuri

\section{INTRODUCTION}

The increase in global population promotes the most diverse concerns. They can be related to products and services consumption needed to supply basic necessities and to provide comfort, but it is also important when the issue is related to disposal or treatment of residues generated to attend the demands.

The Federal University of Jequitinhonha and Mucuri Valleys (UFVJM), campus JK, located in the city of Diamantina, Minas Gerais State, counts with an Effluent Treatment Plant (ETP). Due to the fact that it is a research pole that possesses a considerable number of laboratories, it will naturally produce an effluent that presents in its composition a large number of chemical compounds such as organic, inorganic, metals and organometallics. Considering specifically anatomy laboratories, one of the most harmful products presents at the sewage released is formaldehyde, which is a substance classified as carcinogenic for humans and animals (IARC, 2012). Cutaneous contact or ingestion of contaminated water are common manners to be exposed to its danger (IARC, 2006).

Formaldehyde is a colourless, gaseous aldehyde, highly reactive formed by oxidation or incomplete combustion of hydrocarbons (Martindale, 1993). It is broadly known and used as a substance responsible for preserving tissue and corpses, presenting anti-septic and disinfectant properties besides of being utilized as a histologic fixative (NCIThesaurus, 2018). Its aqueous solution is known as formalin, with formaldehyde concentration around $37-40 \%$ and methanol 10-15\%, approximately, both percentages are in weight. Methanol needs to be added in order to prevent formaldehyde polymerization (Guimarães et al., 2012). However, this substance presents substantial versatility to the industry, for example to the pharmaceutical, cosmetic, organic synthesis industries, among others, considering that formaldehyde is found in combustion gases and in some resins too (Christoskova; Stoyanova, 2002; Franz et al., 2016).

The usage of this compound, whether in industrial processes or for the preservation of corpses, will generate effluents containing it in different concentrations. One of the possibilities is by residuals water, which will eventually be driven to bodies of water as rivers, lakes or seas (Yuan et al., 2017). Added to this, there is a huge concern about its toxicity and carcinogenic effects to humans and to the environment, even in low concentrations (Yang et al., 2017; Grafstrom et al.,
1985; Tišler; Zagorc-Končan, 1997). The danger involved in the indiscriminate disposal of formaldehyde in the environment attracted the attention of researchers and, consequently, different methods of formaldehyde degradation have been proposed, namely: adsorption, photocatalysis and thermic catalysis. Microorganisms can be used as catalytic agents and even noble metals associated with some oxides (Yang et al., 2017; Oliveira; Zaiat, 2005).

Brazilian legislation does not present information about allowed levels of formaldehyde in an effluent (CONAMA, 2005). Hohreiter and Rigg (2001) in partnership with the United States Environmental Protection Agency (USEPA's) established quality criteria to the aquatic life in contact with formaldehyde limited to $1.61 \mathrm{mg} \mathrm{L}^{-1}$ in a chronic condition.

At UFVJM there are two anatomy laboratories, one of them belongs to the Basic Sciences and Healthy Department, dealing with human anatomic pieces, whilst the other one belongs to the Livestock Sciences Department that develops studies with animal anatomic pieces. Both of them discard effluent containing formaldehyde. The methodology and physical structure used in both cases are quite similar. Generally, the corpses or carcasses are kept in tanks with formalin at $8-10 \%(\mathrm{w} / \mathrm{w})$. Oliveira and Zaiat (2005) characterized this solution responsible to preserve corpses. Table 1 presents data from this analysis. Previously to the use of the pieces, it is necessary to wash them, otherwise, everyone in contact with them will be in considerable danger besides of the unpleasant odour. This procedure is repeated weekly.

\section{Table 1 - Characterization of corpse preservation fluid.}

\begin{tabular}{cc}
\hline Parameter & Value \\
\hline Formaldehyde $\left[\mathrm{mg} \mathrm{L}^{-1}\right]$ & 32362.6 \\
Gross COD $\left[\mathrm{mg} \mathrm{L}^{-1}\right]$ & 50783.0 \\
COD Filtered $\left[\mathrm{mg} \mathrm{L}^{-1}\right]$ & 48400.0 \\
$\mathrm{pH}$ & 5.1 \\
Total Solids $\left[\mathrm{mg} \mathrm{L}^{-1}\right]$ & 11220.0 \\
Total Volatile Solids $\left[\mathrm{mg} \mathrm{L}^{-1}\right]$ & 7840.0 \\
Total Suspended Solids $\left[\mathrm{mg} \mathrm{L}^{-1}\right]$ & 57.2 \\
Volatile Suspended Solids $\left[\mathrm{mg} \mathrm{L}^{-1}\right]$ & 45.2 \\
\hline
\end{tabular}

From: Oliveira; Zaiat, 2005. Adapted.

Usually, in the basic learning cycle of human anatomy, the first two weeks are devoted to teaching about bones, also called dry pieces. Only after this period is initiated the process with humid pieces, in other words, pieces stored in a formaldehyde solution in order to keep them preserved. On the other hand, studies with neuroanatomy deal with pieces conserved in formaldehyde since the beginning of the teaching period. In general, the corpses that will be studied are removed from the tanks with formaldehyde $(10 \% \mathrm{w} / \mathrm{w})$ at the beginning of the week, then they are transferred to a surface so that part of the solution is drained and finally, they are carried to a tank 
filled with water in order to promote washing. At this moment, the remaining formaldehyde is diluted, allowing that people may have contact with the pieces. At the end of the week, the washed corpses need to be returned to the tanks with formaldehyde $(10 \% \mathrm{w} / \mathrm{w})$ and the washing water is discarded to the sewage that is direcarded to the ETP.

The animal anatomy laboratory's methodology follows a similar pattern to the human anatomy laboratory, however, the bones study period lasts, approximately, six weeks, these being the initials ones. Whilst the humid pieces activities occur, on average, over the next eight weeks. The washing process, nonetheless, presents subtle differences. The carcasses are transferred in the beginning of the week and washed in tanks filled with water. However, in the first two days, for approximately three hours a day, there is a continuous flow of water inlet and outlet of this tank. The pieces are kept in these tanks until the end of the week to promote the dilution of formaldehyde. After the academic activities, the carcass return to the tanks with formaldehyde $(10 \% \mathrm{w} / \mathrm{w})$ and the washing water is discarded.

Advanced Oxidation Processes (AOP's) are capable of form a hydroxyl radical $\left(\mathrm{OH}^{*}\right)$, which is extremally unstable and highly reactive. $\mathrm{UV}-\mathrm{O}_{3}, \mathrm{UV}-\mathrm{H}_{2} \mathrm{O}_{2}, \mathrm{UV}-\mathrm{TiO}_{2}$, Fenton process and UV-Fenton are examples of processes classified as AOP's. They have been studied as a possible and efficient alternative to diverse areas of effluent treatment due to its considerable capability to convert recalcitrant contaminants in compounds with lower risk or smaller chains allowing simpler treatments afterwards (Legrini; Oliveiros; Braun, 1993; Ruppert; Bauer; Heisler, 1994; Esplugas et al., 2002; Chu et al., 2012).

Other kinds of processes capable of oxidate formaldehyde are available; however, they form formic acid, a reaction product that easily degrades metallic materials usually present in components such as pumps, reactors, and pipes (Yumura et al., 2002; Guimarães et al., 2012). For this reason, the aim of the present study was to seek for a process that allowed formaldehyde mineralization, producing, predominantly, water and carbon dioxide.

The process known as photo-Fenton or UV-Fenton consists in a reaction that induces ferrous ions to combine with hydrogen peroxide under irradiation of ultraviolet light producing a huge degrading photochemical power. A scheme of the Fenton process is demonstrated in Equation 1 (Fenton, 1894; Pérez-Moya et al., 2008). Adding an irradiation source leads to a positive effect on the degradation rate of organic pollutants. Equation 2 represents the reduction of $\mathrm{Fe}^{3+}$ into $\mathrm{Fe}^{2+}$ (Safarzadeh-Amiri; Bolton; Carter, 1996). Reactions involving $\mathrm{Fe}^{3+}$ and hydrogen peroxide regenerating $\mathrm{Fe}^{2+}$ can also occur, as shown in Equations 3 and 4, being called then Fenton-like process, allowing that Fenton process might happen again (Pignatello, 1992).

$$
\begin{aligned}
& \mathrm{Fe}^{2+}+\mathrm{H}_{2} \mathrm{O}_{2} \rightarrow \mathrm{Fe}^{3+}+\mathrm{OH}^{\bullet}+\mathrm{OH}^{-} \\
& \mathrm{FeOH}^{2+}+\mathrm{hv} \rightarrow \mathrm{Fe}^{2+}+\mathrm{OH}^{\bullet} \\
& \mathrm{Fe}^{3+}+\mathrm{H}_{2} \mathrm{O}_{2} \rightarrow \mathrm{Fe}^{2+}+\mathrm{OH}_{2}^{\bullet}+\mathrm{H}^{+} \\
& \mathrm{Fe}^{3+}+\mathrm{OH}_{2}^{\cdot} \rightarrow \mathrm{Fe}^{2+}+\mathrm{O}_{2}+\mathrm{H}^{+}
\end{aligned}
$$

Utset et al. (2000) defend that molecular oxygen can participate in the mineralization of some compounds, it would partially replace $\mathrm{H}_{2} \mathrm{O}_{2}$ by acting like an electron acceptor.
Iron removal after the Fenton process is characterized as a difficulty faced in adopting this process. As stated by Walling and Kato (1971), a considerable number of small flocs is produced during the Fenton oxidation; these flocs are ferric hydroxo complexes of various sizes. Conforming to Lin, Lin and Leu (1999) the flocs can be removed rapidly and affectively by using chemical coagulation with polyaluminum chloride (PAC) and polymer, reducing dissolved COD and turbidity (NTU). Conventionally, it is necessary neutralization and precipitation steps for the separation of the generated sludge. Usually, high times are required due to the low sedimentability of this by-product, increasing, significantly, the treatment time (Moravia; Lange; Amaral, 2011).

Fenton's reagent might have different effects on the treatment, relying on the $\mathrm{H}_{2} \mathrm{O}_{2} / \mathrm{FeSO}_{4}$ ratio. If the amount of $\mathrm{H}_{2} \mathrm{O}_{2}$ used exceeds the $\mathrm{Fe}^{2+}$, the treatment will have the effect of chemical oxidation. When that ratio is reversed, the effect of the treatment will present the effect of chemical coagulation (Neyens; Baeyens, 2003).

Hydrogen peroxide can interfere with some analysis, such as COD, and whether its use precedes a biological treatment, the efficiency of the treatment may be affected (Teixeira; Jardim, 2004).

Kajitvichyanukul and co-workers (2008) elaborated a study analyzing synthetic formalin degradation, composed of $37 \%$ of formaldehyde and $10 \%$ methanol, by UV-Fenton process using a $1.1 \mathrm{~L}$ batch reactor at $25^{\circ} \mathrm{C}$. It was possible to observe that initial $\mathrm{pH}$, concentrations of hydrogen peroxide, ferrous ions and methanol influence the formaldehyde oxidation rate. The complete reaction presents three evident stages, as clearly shown in Figure 1 . The first step, the $\mathrm{Fe}^{2+} / \mathrm{H}_{2} \mathrm{O}_{2}$ stage, happens during the first five minutes of reaction, as a fast decomposition. The second one, occurring between five to twenty minutes, is a transition phase. After twenty minutes of reaction, the third stage takes place until the end of the reaction; it is characterized by the decline of oxidation rate, the $\mathrm{Fe}^{3+} / \mathrm{H}_{2} \mathrm{O}_{2}$ stage, obeying a pseudo-first order kinetic.

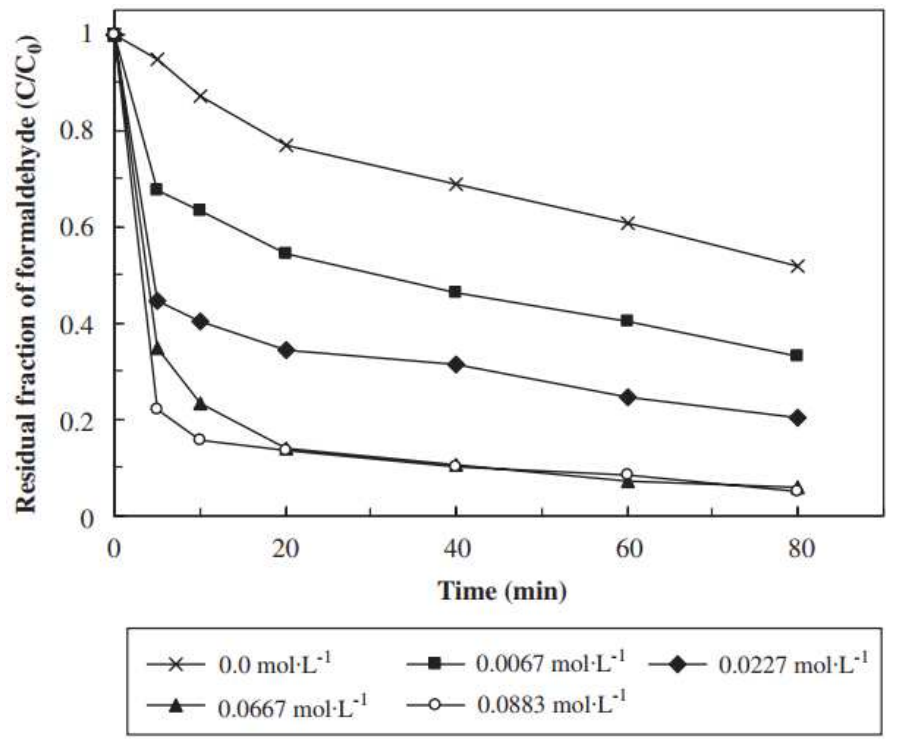

Figure 1 - Effect of initial concentrations of ferrous ions on photooxidation of formaldehyde; experiment condition: $\left[\mathrm{CH}_{2} \mathrm{O}\right]=0.3330 \mathrm{~mol} \mathrm{~L}^{-1},\left[\mathrm{H}_{2} \mathrm{O}_{2}\right]=0.6670 \mathrm{~mol} \mathrm{~L}^{-1}, \mathrm{pH}=2.6$ $( \pm 0.1)$.

From: Kajitvichyanukul; Lu; Jamroensan, 2008. Adapted. 
Even though in the Kajitvichyanukul and co-workers (2008) study and in other works those three stages are quite clear, there is not enough kinetic data for the complete reaction. Particularly considering the information released by Kajitvichyanukul and co-workers (2008) only two of the three stages have kinetic data. Comparing to the other sources (Kajitvichyanukul et al., 2006; Liu; Liang, Wang, 2011; Guimarães et al., 2012), Kajitvichyanukul and co-workers (2008) study provided a considerable amount of kinetic data. In order to establish the modelling and simulation for this entire process, some adaptations from the original work were demanded. This study used concentrations of formaldehyde, hydrogen peroxide, ferrous ions equals to $0.3330 \mathrm{~mol} \mathrm{~L}^{-1}$, $0.6670 \mathrm{~mol} \mathrm{~L}^{-1}$ and $0.0883 \mathrm{~mol} \mathrm{~L}^{-1}$, respectively, and $\mathrm{pH}$ equals to $2.6( \pm 0.1)$. Figure 1 also provides an initial rate equals to $0.0457 \mathrm{~mol} \mathrm{~L}^{-1} \mathrm{~min}^{-1}$ for the first stage and specific reaction rate equals to $0.0154 \mathrm{~min}^{-1}$ for the third stage.

Besides the modelling and simulation of the process, the focus of this study was to analyze the best reactional system to the residue treatment generated by the mentioned anatomy laboratories and to determinate adequate design to the reactor chosen based on those laboratories methodology.

\section{MATERIAL AND METHODS}

\subsection{Modelling and Simulation}

The first five minutes of reaction is characterized as the first stage, which the initial rates were defined in Kajitvichyanukul, Lu, and Jamroensan (2008) study. At this point it was proposed an alteration of concept; at the present study this first stage is considered as a zero-order reaction, as presented at Equation 5, whose specific reaction rate, $k$, has the same value which was once called initial rate.

$$
-r_{A}=k_{1}
$$

where $r_{A}$ is the reaction rate of formaldehyde decomposition in $\mathrm{mol} \mathrm{L}^{-1}, k_{1}$ is the specific reaction rate for the first stage in $\mathrm{mol} \mathrm{L} \mathrm{L}^{-1} \mathrm{~min}^{-1}$.

The third stage was defined as following a pseudo-first order kinetic, initiating after twenty minutes of reaction. Although considering the condition of formaldehyde, $0.3330 \mathrm{~mol} \mathrm{~L}^{-1}$, hydrogen peroxide, $0.6670 \mathrm{~mol} \mathrm{~L}^{-1}$, ferrous ions, $0.0883 \mathrm{~mol} \mathrm{~L}^{-1}$ and $\mathrm{pH}=2.6( \pm 0.1)$, it is possible to observe a linear tendency after the first ten minutes of reaction. In other words, in this case, the third stage, following a pseudofirst order, seen at Equation 6, initiate after ten minutes of reaction.

$$
-r_{A}=k_{3} C_{A}
$$

where $k_{3}$ is the specific reaction rate for the third stage in $\min ^{-1}$ and $C_{A}$ is the molar concentration of formaldehyde in $\mathrm{mol} \mathrm{L}^{-1}$.

Differently, from the stages one and three, the second stage was just pointed as a transition stage, without kinetic data. Aiming to restructure this stage, its duration was reviewed, now occurring between five to ten minutes of reaction and also following a pseudo-first order kinetics, shown in Equation 7. Figure 2 presents more clearly how the three stages were restructured at the present study.

$-r_{A}=k_{2} C_{A}$

where $k_{2}$ is the specific reaction rate for the second stage determinated in $\min ^{-1}$.

The determination of a kinetic model allowed tests of different reactional systems able to lead formaldehyde mineralization in aqueous solution. Among all the possibilities, considering the simplicity of the models involved, three systems were evaluated: Batch Stirred Tank Reactor, BSTR, a Continuous Stirred Tank Reactor, CSTR, and a Plug Flow Reactor, PFR.

Mathematical models used to represent the operation of the BSTR, CSTR and PFR can be seen at Equations 8 to 10, respectively. Due to the reaction occurs in the liquid phase the models do not consider volumetric variations.

$$
\begin{aligned}
-r_{A} & =-\frac{d C_{A}}{d t} \\
-r_{A} & =-\frac{\left(v_{0} C_{A 0}-v C_{A}\right)}{V} \\
-r_{A} & =-v_{0} C_{A 0} \frac{d x_{A}}{d V}
\end{aligned}
$$

where $t$ is time, $V$ is volume, $C_{A O}$ is the initial molar concentration of formaldehyde, $v_{0}$ is the initial volumetric flow, due to the fact that this is a liquid system, so the variation of the volumetric flow is negligible, and $x_{A}$ is the conversion of formaldehyde.

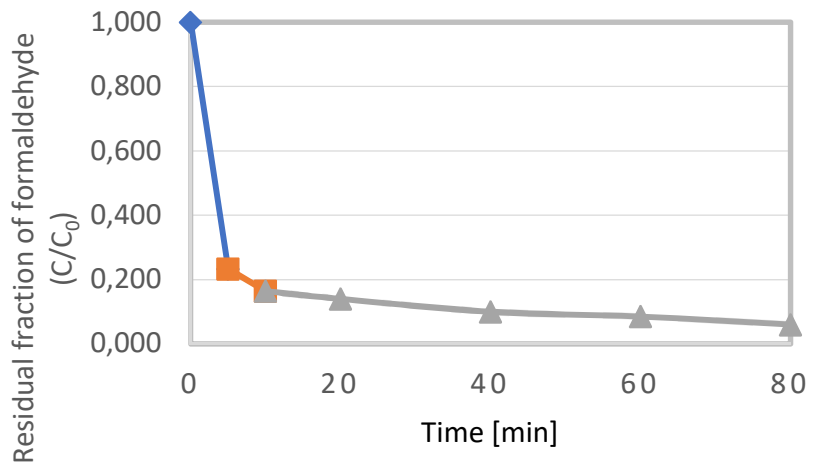

$$
\sim \text { 1st Stage } \quad-2 \text { nd Stage } \quad-3 \text { rd Stage }
$$

\section{Figure 2 - Restructuring of the three stages of formaldehyde photooxidation.}

In order to get simpler analysis and comparison between each one of the systems, it was considered the same volume for all the reactors, $1.1 \mathrm{~L}$, the reactional volume from Kajitvichyanukul, Lu, and Jamroensan (2008) study and the same reaction conditions.

\subsection{Reactor Choose and Design}

The reactor design was developed aiming to accomplish a safe disposal, according to the literature, of $1.61 \mathrm{mg} \mathrm{L}^{-1}$ of formaldehyde.

The concentrations of formaldehyde present in the effluent generated after washing anatomic pieces were determined considering as occurring fifty-fold dilution of the formaldehyde, $8-10 \%(\mathrm{w} / \mathrm{w})$, used in the tanks responsible to maintain the corpses preserved, which is approximately $32.4 \mathrm{~g} \mathrm{~L}^{-1}$ of formaldehyde, as provided in Oliveira and Zaiat's (2005) study. The fifty-fold dilution, $647.25 \mathrm{mg} \mathrm{L}^{-1}$ of formaldehyde, was fixed due to the fact that the number of 
pieces washed constantly varies and distinct anatomic pieces have different capabilities of absorption of formaldehyde; for example, a gut is capable of absorbing much more formaldehyde solution than an arm. Consequently, different amounts of formaldehyde will be dissolved during the washing process.

Mean values of the volume of disposal were used to determine the dimensions of the reactors and again Equations 8 to 10 were applied.

In addition to this information, there was an attempt to calculate the highest concentration of formaldehyde that the reactors would be able to degrade and provide a final result that is lower than the value of $1.61 \mathrm{mg} \mathrm{L}^{-1}$ indicated in the literature.

Assuming that the BSTR would be filled with the fluid stored in an equalization tank, relying only on the flow generated by the action of gravity, counting on the same mechanism to empty the reactor. The necessary time to fill or empty a tank is calculated using Equation 11.

$$
t=\frac{-2 A\left(\sqrt{h_{2}}-\sqrt{h_{1}}\right)}{S C_{d} \sqrt{2 g}}
$$

where $t$ is time, $A$ is the cross-section area which belongs to the tank that will be emptied, $h_{l}$ is the initial height of the liquid, $h_{2}$ is the final height of the liquid, $S$ is the cross-section area relative to the outlet orifice, $C_{d}$ is the discharge coefficient and $g$ is the acceleration of gravity.

The value of the discharge coefficient was used based on the fluid outlet nozzle; here the value chosen was 0.82 (Netto et al., 1998), and the acceleration of gravity was considered as $9.8 \mathrm{~m} \mathrm{~s}^{-2}$.

\section{RESULTS AND DISCUSSION}

\subsection{Modelling and Simulation}

The subtle changes in the data from the referenced document were needed in order to accomplish the entire reaction modelling and simulation. The specific reaction rate of the first stage kept the same value that was previously called initial rate, in another hand, it was necessary to calculate this parameter to the second stage and recalculate to the third stage. Table 2 presents the values and units for each one of these parameters, they were calculated using data from Figure 2.

Table 2 - Specific reaction rates for each stage.

\begin{tabular}{cccc} 
& $\mathbf{1}^{\text {st }}$ Stage & $\mathbf{2}^{\text {nd }}$ Stage & $\mathbf{3}^{\text {rd }}$ Stage \\
\hline $\begin{array}{c}\text { Specific } \\
\text { Reaction Rate }\end{array}$ & $0.0457 \frac{\mathrm{mol}}{\mathrm{L} \mathrm{min}}$ & $0.0702 \frac{1}{\mathrm{~min}}$ & $0.0144 \frac{1}{\mathrm{~min}}$ \\
\hline
\end{tabular}

The value provided by Kajitvichyanukul, Lu, and Jamroensan (2008) for the first stage, $0.0457 \mathrm{~mol} \mathrm{~L}^{-1} \mathrm{~min}^{-1}$, seen in Table 1, was kept. However, in order to ensure its veracity, when calculated this parameter, considering zero-order kinetic, the value found was very close, equals to $0.0511 \mathrm{~mol} \mathrm{~L}^{-1} \mathrm{~min}^{-1}$. Therefore, the maintenance of the original value is quite acceptable.

The second stage, differently from the anteriorly mentioned, do not present kinetic data from the text used as a reference. Its duration change, beginning at five minutes until ten minutes of reaction, and considering it following a pseudofirst order kinetic the specific reaction rate was calculated and presented in Table 2.

Finally, at the third and last stage the pseudo-first order kinetic was preserved, but in this analysis, this stage started after ten minutes of reaction. The calculation since that adjustment presented specific reaction rate as $0.0144 \mathrm{~min}^{-1}$, as exposed at Table 2 . The value found in the reference study was $0.0154 \mathrm{~min}^{-}$ ${ }^{1}$, once more is possible to observe a very acceptable adjustment, with changes only at the third decimal place.

\subsection{Reactor Choose and Design}

The comparison between the reactors was based on time of reaction, when dealing with a BSTR, and mean residence time, for the CSTR and PFR, which operate continuously. The same volume was kept for all three reactors, $1.1 \mathrm{~L}$, the kinetic parameter present in Table 2 and the Equations 5 to 7 were used. The results obtained from BSTR, CSTR and PFR might be checked at Tables 3 to 5, respectively.

Table 3 - Reaction time for the batch reactor.

\begin{tabular}{|cccc|}
\hline \multicolumn{4}{c|}{ BSTR } \\
\hline \multicolumn{4}{c|}{ Reaction time [min] } \\
\hline $\mathbf{1}^{\text {st }}$ Stage & $\mathbf{2}^{\text {nd }}$ Stage & $\mathbf{3}^{\text {rd }}$ Stage & Total \\
5.59 & 5.00 & 70.00 & 80.59 \\
\hline
\end{tabular}

Table 4 - Residence time for the CSTR.

\begin{tabular}{cccc}
\hline \multicolumn{4}{c}{ CSTR } \\
\hline \multicolumn{4}{c}{ Residence time [min] } \\
\hline $\mathbf{1}^{\text {st }}$ Stage & $\mathbf{2}^{\text {nd }}$ Stage & $\mathbf{3}^{\text {rd }}$ Stage & Total \\
5.59 & 5.99 & 120.67 & 132.25 \\
\hline
\end{tabular}

Table 5 - Residence time for the PFR.

\begin{tabular}{cccc}
\hline \multicolumn{4}{c}{ PFR } \\
\hline \multicolumn{4}{c}{ Residence time [min] } \\
\hline $\mathbf{1}^{\text {st }}$ Stage & $\mathbf{2}^{\text {nd }}$ Stage & $\mathbf{3}^{\text {rd }}$ Stage & Total \\
5.59 & 5.00 & 70.00 & 80.59 \\
\hline
\end{tabular}

Designing a batch reactor and a PFR, selected after analysis of the results from Tables 3 to 5, was made considering the mean volume disposed by the anatomy laboratories and the concentration of formaldehyde corresponds to a fifty-fold dilution from a solution with $32362.6 \mathrm{mg} / \mathrm{L}$ of formaldehyde. These results can be followed in Table 6 .

It is pursued a treatment capable to reduce the concentration of formaldehyde in up to $1.61 \mathrm{mg} \mathrm{L}^{-1}$, at least. The essential condition to achieve a residue that is not harmful to the environment according to the literature. Converting it into a molar concentration, it becomes $0.000054 \mathrm{~mol} \mathrm{~L}^{-1}$. For that reason, it is expected a suitable design that attends this limitation. 
Table 6 - Mean volume and concentration of the solution weekly disposed of.

\begin{tabular}{|c|c|c|c|}
\hline & $\begin{array}{c}\text { Mean } \\
\text { Volume [L] }\end{array}$ & $\begin{array}{l}\text { Mean C } \\
{\left[\mathrm{mg} \mathrm{L}^{-1}\right]}\end{array}$ & $\begin{array}{l}\text { entration } \\
{[\mathrm{mol} \mathrm{L}} \\
\end{array}$ \\
\hline $\begin{array}{c}\text { Human } \\
\text { Anatomy } \\
\text { Laboratory }\end{array}$ & 65 & 647.25 & 0.0216 \\
\hline $\begin{array}{c}\text { Animal } \\
\text { Anatomy } \\
\text { Laboratory }\end{array}$ & 1585 & 647.25 & 0.0216 \\
\hline Total & 1650 & 647.25 & 0.0216 \\
\hline
\end{tabular}

In view of the kinetic data used, the maximum concentration of formaldehyde that can be processed is $6856.48 \mathrm{mg} \mathrm{L}^{-1}$ or $0.2285 \mathrm{~mol} \mathrm{~L}^{-1}$, which is equivalent to a 4.72 fold dilution.

Considering $1650 \mathrm{~L}$ of solution with $0.0216 \mathrm{~mol} \mathrm{~L}^{-1}$ as the initial concentration, this is the union of the disposal from both laboratories to be weekly treated by the batch reactor or the PFR. A closer look at the specific reaction rate obtained to the first stage, $0.0457 \mathrm{~mol} \mathrm{~L}^{-1} \mathrm{~min}^{-1}$, and to the formaldehyde initial concentration, $0.0216 \mathrm{~mol} \mathrm{~L}^{-1}$, leads to realizing that it is possible to notice that those five minutes reaction time, for BSTR, or mean residence time, for PFR, are more than enough to complete the reaction. More specifically, in almost 29 seconds the desired conversion is already conquered. It was possible to observe previously that, working with the same volume of reactors and the reaction time equals to the residence time, the reactors will achieve the same conversion, consequently, the same final concentration. The only difference exists because of the PFR is operated continuously, whilst the batch reactor is not.

Due to this, the batch time is not only the reaction time, including feeding, emptying and cleaning times too. Different volumes of the batch reactor were simulated in order to calculate the batch time and how many batches would be needed. Every situation analysed presented feeding and emptying times, each one of them less than one minute. Consequently, batch time was fixed as 7 minutes, in other words, 5 minutes of reaction, 1 minute feeding and 1 minute emptying, all of them were overvalued. Then, supposing $150 \mathrm{~L}$ the volume of the BSTR, batch time was valued at 7 minutes, with 11 batches the entire treatment would be achieved. It would take slightly more than an hour of operation in total.

On the other hand, a PFR with $6 \mathrm{~L}$ would demand a feeding and emptying volumetric rate of $1.2 \mathrm{~L} \mathrm{~min}^{-1}$, continuously, for just over one day. That is, the PFR would require leastwise one pump and the batch reactor would not, at least not mandatorily.

\section{CONCLUSION}

The formaldehyde oxidation reaction in aqueous solution was modelled in three different stages, determining the first one following a zero-order kinetic and the other two stages following a pseudo-first order kinetic. The specific reaction rates were calculated or recalculated for each stage.

The definition of specific reaction rates for the three stages was fundamental to allow the comparison between the types of reactor, BSTR, CSTR and PFR, with the same volume. As expected, the CSTR needed more mean residence time, comparing to the PFR. It is justified because of the ideal model of operation usual for a CSTR. The concentration inside the reactor is the same if compared with the concentration that comes out of the reactor. In other words, the reaction rate in which the CSTR operates is slower than the PFR. Then, with the same volume, in order to achieve equal final concentration, the CSTR will need longer residence time, leading in this case to a lower volumetric flow, and consequently, longer treatment time.

The models of BSTR and PFR, the first operating discontinuously and the last continuously, justifies the PFR be able to process the treatment more quickly. Relying on the reactor size and the amount of residue to be mineralized its use ought not to be acceptable, once it will request the use of a pump, which might be an energetically negative point.

However, it is important to emphasize that the reference article which provided the reaction kinetic data for this study worked based on a synthetic effluent, a different situation when compared to the solution generated by the anatomy laboratories. The residue disposed by these laboratories contains organic compounds from the anatomic pieces besides of the formaldehyde solution. The oxidative process which the effluent is submitted is suited to oxide all of them, formaldehyde, methanol and organic compounds, present in the solution interfering at the formaldehyde mineralization. As a consequence, the process involving a real effluent is considerably slower compared to the treatment of a synthetic effluent, as a result of higher COD in the solution treated.

The reaction rate will vary relying on the initial concentration, however, it is important to emphasize that the reaction specific rate might change too because of the presence of other organic compounds. In order to obtain values more accurately, tests should be conducted on the solution that would be discarded to the sewer.

Even in very low concentration, it is possible that some formic acid is produced during the formaldehyde mineralization process. For this reason, the use of a reactor made from materials resistant to corrosion is fundamental. A BSTR fabricated in glass-lined steel ought to be an adequate option in this case.

As a suggestive way of continuing this study, tests should be developed with the solution discharged by the laboratories and the kinetic data specific to the mineralization using UVFenton process ought to be analysed and discussed. Only after that, both kinetic models can be compared to verify its similarities and differences. In addition, there is the possibility of studying the implementation of a separation system, which has neutralization and precipitation steps, aiming to remove iron from the rest of the treated effluent before being disposed of in the sewage, and automating the process by developping a control system of filling and emptying the reactor.

\section{R E F E R E N C E S}

CHRISTOSKOVA, S.; STOYANOVA, M. Catalytic degradation of $\mathrm{CH}_{2} \mathrm{O}$ and $\mathrm{C}_{6} \mathrm{H}_{5} \mathrm{CH}_{2} \mathrm{OH}$ in wastewater. Water Research, v. 36, n. 9, p. 2297-2303, 2002.

CHU, L.; WANG, J.; DONG, J.; LIU, H.; SUN, X. Treatment of coking wastewater by an advanced Fenton oxidation process using iron powder and hydrogen peroxide. 
Chemosphere, v. 86, n. 4, p. 409-414, 2012.

CONAMA. Resolução $\mathrm{N}^{\circ}$ 357, 2005. Available at: http://www.mma.gov.br/port/conama/res/res05/res3570 5.pdf. Accessed on November 16 $6^{\text {th }}, 2017$.

ESPLUGAS, S.; GIMÉNEZ, J.; CONTRERAS, S.; PASCUAL, E.; RODRÍGUEZ, M. Comparison of different advanced oxidation processes for phenol degradation. Water Research, v. 36, n. 4, p. 1034-1042, 2002.

FENTON, H. J. H. LXXIII. - Oxidation of tartaric acid in presence of iron. Journal of the Chemical Society, Transactions, The Royal Society of Chemistry, v. 65, p. 899-910, 1894.

FRANZ, A. W.; KRINEMAYER, H.; PFEIFFER, D.; PILZ, R. D.; REUSS, G.; DISTELDORF, W.; GAMER, A. O.; HILT, A. Formaldehyde. In:__. Ullmann's Encyclopedia of Industrial Chemistry. American Cancer Society, 2016. p. 1-34.

GRAFSTROM, R. C.; CURREN, R. D.; YANG, L. L.; HARRIS, C. C. Genotoxicity of formaldehyde in cultured human bronchial fibroblasts. Science, American Association for the Advancement of Science, v. 228, n. 4695, p. 89-91, 1985.

GUIMARÃES, J. R.; FARAH, C. R. T.; MANIERO, M. G.; FADINI, P. S. Degradation of formaldehyde by advanced oxidation processes. Journal of Environmental Management, v. 107, p. 96-101, 2012.

HOHREITER, D. W.; RIGG, D. K. Derivation of ambient water quality criteria for formaldehyde. Chemosphere, v. 45, n. 4, p. 471-486, 2001.

IARC. Chemical agents related occupations. IARC Monographs on the Evaluation of Carcinogenic Risks to Humans, v. 100F, p. 1-599, 2012.

IARC. Formaldehyde, 2-butoxyethanol and 1tertbutoxypropan-2-ol. IARC Monographs on the Evaluation of Carcinogenic Risks to Human, v. 88, p. 1-478, 2006.

KAJITVICHYANUKUL, P.; LU, M.; JAMROENSAN, A. Formaldehyde degradation in the presence of methanol by photo-Fenton process. Journal of Environmental Management, v. 86, n. 3, p. 545-553, 2008.

KAJITVICHYANUKUL, P.; LU, M.; LIAO, C.; WIROJANAGUD, W.; KOOTTATEP, T. Degradation and detoxification of formaline wastewater by advanced oxidation processes. Journal of Hazardous Materials, v. 135, n. 1, p. 337-343, 2006.

LEGRINI, O.; OLIVEROS, E.; BRAUN, A. M. Photochemical processes for water treatment. Chemical Reviews, v. 93, n. 2, p. 671-698, 1993.

LIN, S. H.; LIN, C. M.; LEU, H. G. Operating characteristics and kinetic studies of surfactant wastewater treatment by Fenton oxidation. Water Research, v. 33, n. 7, p. 1735$1741,1999$.

LIU, X.; LIANG, J.; WANG, X. Kinetics and reaction pathways of formaldehyde degradation using UV-Fenton method. Water Environment Research, v. 83, n. 5, 2011.

MARTindale, W. The Extra Pharmacopoeia, $30^{\text {th }}$ ed., Londres: Pharmaceutical Press, 1993.

MORAVIA, W. G.; LANGE, L. C.; AMARAL, M. C. S. Avaliação de processo oxidativo avançado pelo reagente de Fenton em condições otimizadas no tratamento de lixiviado de aterro sanitário com ênfase em parâmetros coletivos e caracterização do lodo gerado. Química
Nova, v. 34, n. 8, p. 1370-1377, 2011.

NCITHESAURUS. Formaldehyde, 2018. Available at: https://ncit.nci.nih.gov/ncitbrowser/ConceptReport.jsp? dictionary=NCI_Thesaurus\&ns=NCI_Thesaurus\&code $=\mathrm{C} 29744$. Accessed on April 16 ${ }^{\text {th }}, 2018$.

NETTO, A; FERNANDEZ, M. F.; ARAÚJO, R.; ITO, A. E. Manual de hidráulica. $8^{\text {th }}$ ed., São Paulo: Edgard Blücher Ltda, 1998.

NEYENS, E.; BAEYENS, J. A review of classic Fenton's peroxidation as an advanced oxidation technique. Journal Hazardous Materials, v. B98, p. 33-50, 2003.

OLIVEIRA, S. V. W. B.; ZAIAT, M. Gerenciamento de solução de formol em laboratórios de anatomia. Revista Brasileira de Ciências Ambientais, n. 1, p. 18-25, 2005.

PÉREZ-MOYA, M.; GRAELLS, M.; BUENESTADO, P.; MANSILLA, H. A comparative study on the empirical modelling of photo-Fenton treatment process performance. Applied Catalysis B: Environmental, v. 84, n. 1, p. 313-323, 2008.

PIGNATELLO, J. J. Dark and photoassisted $\mathrm{Fe}^{3+}$ catalysed degradation of chlorophenoxy herbicides by hydrogen peroxide. Environmental Science \& Technology, v. 26, n. 5, p. 944-951, 1992.

RUPPERT, G.; BAUER, R.; HEISLER, G. UV-O $\mathrm{O}_{3}, \mathrm{UV}-\mathrm{H}_{2} \mathrm{O}_{2}$, $\mathrm{UV}-\mathrm{TiO} 2$ and the photo-Fenton reaction - comparison of advanced oxidation processes for wastewater treatment. Chemosphere, v. 28, n. 8, p. 1447-1454, 1994.

SAFARZADEH-AMIRI, A.; BOLTON, J. R.; CATER, S. R. A comparative study on the empirical modeling of photoFenton treatment process performance. Applied Catalysis B: Environmental, v. 1, n. 1, p. 18-26, 1996.

TEIXEIRA, C. P. A. B.; JARDIM, W. F. Processos oxidativos avançados: conceitos teóricos, Caderno Temático, v. 3, Laboratório de Química Ambiental - LQA, Instituto de Química - UNICAMP, Campinas - SP, 2004.

TIŠLER, T.; ZAGORC-KONČAN, J. Comparative assessment of toxicity of phenol, formaldehyde, and industrial wastewater to aquatic organisms. Water, Air and Soil Pollution, v. 97, n. 3, p. 315-322, 1997.

UTSET, B.; GARCIA, J.; CASADO, J.; DOMÈNECH, X.; PERAL, J. Replacement of $\mathrm{H}_{2} \mathrm{O}_{2}$ by $\mathrm{O}_{2}$ in Fenton and photo-Fenton reactions. Chemosphere, v. 41, n. 8, p. 1187-1192, 2000.

WALLING, C.; KATO, S. Oxidation of alcohols by Fenton's reagent. Effect of copper ion. Journal of the American Chemical Society, v. 93, n. 17, p. 4275-4281, 1971.

YANG, T.; HUO, Y.; RUI, Z.; JI, H. Efficient formaldehyde oxidation over nickel hydroxide promoted $\mathrm{Pt} / \gamma-\mathrm{Al}_{2} \mathrm{O}_{3}$ with a low Pt content. Applied Catalysis B: Environmental, v. 200, p. 543-551, 2017.

YUAN, D.; TIAN, L.; GU, D.; SHEN, X.; ZHU, L.; WU, H.; WANG, B. Fast and efficient oxidation of formaldehyde in wastewater via the solar thermal electrochemical process tuned by thermoelectrochemistry. Journal of Cleaner Production, v. 156, p. 310-316, 2017.

YUMURA, T.; AMENOMORI, T.; KAGAWA, Y.; YOSHIZAWA, K. Mechanism for the formaldehyde to formic acid and formic acid to carbon dioxide conversions mediated by an iron-oxo species. The Journal of Physical Chemistry A, v. 106, n. 4, p. 621630, 2002. 